University of Nebraska - Lincoln

DigitalCommons@University of Nebraska - Lincoln

Publications of the University of Nebraska

Public Policy Center

Public Policy Center, University of Nebraska

2016

On the influence of trust in predicting rural land owner cooperation with natural resource management institutions

Joseph A. Hamm

Lesa R. Hoffman

Alan Tomkins

Brian H. Bornstein

Follow this and additional works at: https://digitalcommons.unl.edu/publicpolicypublications

Part of the Natural Resources and Conservation Commons, Natural Resources Management and Policy Commons, Other Public Affairs, Public Policy and Public Administration Commons, Other Social and Behavioral Sciences Commons, Public Affairs Commons, Public Policy Commons, Social Policy Commons, and the Water Resource Management Commons

This Article is brought to you for free and open access by the Public Policy Center, University of Nebraska at DigitalCommons@University of Nebraska - Lincoln. It has been accepted for inclusion in Publications of the University of Nebraska Public Policy Center by an authorized administrator of DigitalCommons@University of Nebraska - Lincoln. 


\title{
On the influence of trust in predicting rural land owner cooperation with natural resource management institutions
}

\author{
Joseph A. Hamm, ${ }^{1}$ Lesa Hoffman, ${ }^{2}$ \\ Alan J. Tomkins, ${ }^{3}$ and Brian H. Bornstein ${ }^{4}$ \\ 1 School of Criminal Justice \& Environment Science and Policy Program, Michigan \\ State University, East Lansing, MI, USA \\ 2 Schiefelbusch Institute for Life Span Studies, University of Kansas, Lawrence, \\ KS, USA \\ 3 Public Policy Center, University of Nebraska, Lincoln, NE, USA \\ 4 Department of Psychology, University of Nebraska-Lincoln, Lincoln, NE, USA \\ Corresponding author — J. A. Hamm, email jhamm@msu.edu \\ ORCID Joseph A. Hamm http://orcid.org/0000-0001-9250-3681
}

\begin{abstract}
Contemporary natural resource management (NRM) emphasizes the role of the public in general and land owners in particular as voluntary participants in the process. Understanding the role of trust in voluntary cooperation is therefore critical, but the current state of the relevant literature is such that it fails to systematically address a few important issues. This inquiry sought to address these issues by presenting and testing a model of land owners' trust in and cooperation with a NRM institution. The model hypothesizes that the six major drivers of trust in this context (dispositional trust, care, competence, confidence, procedural fairness and salient values similarity) are distinct but correlated constructs that drive cooperation and whose effects are moderated by the sophistication (relevant knowledge and experience) of the trustor.
\end{abstract}

Published as: Joseph A. Hamm, Lesa Hoffman, Alan J. Tomkins \& Brian H. Bornstein (2016): On the influence of trust in predicting rural land owner cooperation with natural resource management institutions, Journal of Trust Research, Volume 6, Issue 1 (2016), pp 37-62. DOI:10.1080/21515581.2015.1108202

Copyright (c) 2016 Peter Ping Li. Published by Routledge/Taylor \& Francis. Used by permission. Submitted 22 June 2014; accepted 5 October 2015; published 8 January 2016. 
The results provide complicated partial support for the hypotheses and suggest that (1) although the six constructs are separable, their effects on cooperation are not as distinct as expected; (2) the most important consideration for cooperation may, in fact, be a broader evaluation - potentially a willingness to be vulnerable to the target and (3) if sophistication is an important moderator of the effect of trust, it is likely to require only a low level of general sophistication about the target institution to encourage trustors to rely most strongly on their perceptions of the institution itself.

Keywords: trust, cooperation; natural resource management, model of trust, sophistication moderation hypothesis

Natural resource management (NRM) in the USA has undergone a major paradigm shift over the last few decades (Pahl-Wostl et al., 2007; Sabatier et al., 2005). Previously, NRM was driven by equilibrium-centered theories (Holling, 1973) which suggest that resource dynamics can be reliably 'predicted and controlled' (Pahl-Wostl et al., 2007, p. 1) by strong top-down regulation which would also prevent the otherwise inevitable exploitation of these common-pool resources (Hardin, 1968; Pretty, 2003). Consistent with this view, early NRM was typified by instrumental, command-and-control efforts whereby subject expert resource managers set priorities and determined actions with little-to-no input from the broader public.

Recently, however, this approach to NRM has been challenged by a resilience-based approach (Gunderson, Holling, \& Allen, 2010). In place of the reliably predictable resource dynamics that were the premise of the previous management paradigm, resilience theory argues that socioecological systems (SES) exist in one of many possible stable states that are held in balance by any number of expected and unexpected drivers (Holling, 1973). This paradigm argues that in periods of high resilience, the balance created by these drivers enhances the SES's ability to withstand perturbations while maintaining its essential function. In periods of low resilience, however, the stability of the SES is vulnerable and, upon reaching and crossing a critical threshold, the SES will self-reorganize into a new, and potentially distinct stable state (Folke et al., 2004; Martin, Runge, Nichols, Lubow, \& Kendall, 2009). Although considerable work has been done in identifying important thresholds (see WashingtonAllen, Briske, Shugart, \& Salo, 2010), the often unseen nature of many of the drivers of system resilience means that these thresholds are often difficult to identify before they are crossed. Thus the contemporary 
adoption of resilience theory has ushered in a fundamental shift from resource dynamics as knowable and predictable to being chronically uncertain (Briske et al., 2010).

Somewhat in parallel to this shift to resilience-based approaches, many have called for the more explicit incorporation of the broader public (Armitage et al., 2009; Lynam, de Jong, Sheil, Kusumanto, \& Evans, 2007). Following in large part on work by Ostrom (e.g. Ostrom, 1998; Vollan \& Ostrom, 2010), these resource co-management approaches explicitly acknowledge important roles for numerous stakeholders in NRM. Their inclusion is important because it is argued to legitimize the process (Duram \& Brown, 1999) and is believed to increase trust among stakeholders (Armitage et al., 2009; Berkes, 2009; Pahl-Wostl et al., 2007; Pretty, 2003; Selin, Pierskalla, Smaldone, \& Robinson, 2007). Additionally, the explicit inclusion of stakeholders is championed because of the potential for identifying creative solutions that exists when a number of diverse experiences and values are represented in problem-solving (Armitage et al., 2009; Berkes, 2009; Pahl-Wostl et al., 2007; Selin et al., 2007; see also, Frederickson, 2014), an especially critical benefit for NRM given the centrality of uncertainty.

Because of the importance of the public in contemporary approaches to NRM, trust is often argued to be an important prerequisite of effective ecosystem management (Flitcrift, Dedrick, Smith, Thieman, \& Bolte, 2010; Idrissou, van Paassen, Aarts, Vodouhè, \& Leeuwis, 2013). Indeed, research has found that a requisite level of trust is critical for participation in the process (Yandle, Hajj, \& Raciborski, 2011). Beyond the effects on participation, NRM is also postulated to rely heavily on trust because trust influences the 'perceived efficacy and approval of planned or proposed [management] actions' (Winter \& Cvetkovich, 2010, p. 218) and often plays an important role in driving cooperation and compliance (Hamm et al., 2013b; see generally, Leahy \& Anderson, 2008; Liljeblad, Watson, \& Borrie, 2007; Stern, 2008).

\section{Trust in the NRM context}

Within the contemporary NRM paradigm, trust is, therefore, important. Problematically, however, there is not as yet a generally accepted definition of trust in this literature nor an accepted approach to its measurement. There is, however, some guidance which can be obtained by 
evaluating the few existing conceptualizations of trust in this literature in light of research from more developed areas of trust scholarship. Specifically, in the organizational and other contexts, trust is increasingly thought to be a psychological state within the trustor that is characterized by a willingness to accept vulnerability in interactions with the trust target, and that is driven by relevant antecedents that either decrease the perceived vulnerability or increase its acceptability within the trustor (see Hamm et al., 2016; Mayer, Davis, \& Schoorman, 1995; Möllering, 2013; Rousseau, Sitkin, Burt, \& Camerer, 1998; Warren, 1999).

Researchers in the NRM context have begun to take notice of this conceptualization (e.g. Sharp, Twaites, Curtis, \& Millar, 2013; Stern \& Coleman, 2015) and its adoption has two important implications. The first is the importance of recognizing the centrality of vulnerability. Across contexts, the specific role of vulnerability has historically been largely neglected in trust research but a recent review of organizational relationships argues strongly for the need to connect perceived vulnerabilities to all aspects of the process of trust (Nienaber, Hofeditz, \& Romeike, 2015). In the NRM context specifically, much of the potential for harm is economic (e.g. farmers' vulnerability to reduced yields from an unfavorable water allocation), but there are also important, albeit more affective vulnerabilities like a loss of autonomy (e.g. the possibility that regulations would be enacted that encroach on land owners' belief that they are free to determine how best to manage their land) and the possibility that NRM institutions could disregard public interests in resources that are intended to be held in public trust by the management institution (e.g. the possibility that management institutions would permit industrial activity on land that the public considers aesthetically or culturally important).

The second implication of conceptualizing trust in this manner is that it argues for the importance of distinguishing between this willingness to accept vulnerability and the factors that drive it (Mayer et al., 1995). This conceptual precision is important primarily because although the presence or absence of particular drivers of trust may, in some cases, be directly related to the presence or absence of trust, this is not necessarily the case. Problematically however, the literature in this and many other areas of trust research frequently conflates trust with its drivers (Sharp et al., 2013). Within the scholarship that has been more precise, numerous accounts of the drivers of trust exist and noteworthy effort 
has been expended in investigating them in a number of contexts. Importantly however, because trust is fundamentally tied to the context in which it occurs (Mayer et al., 1995), it is important that research develop and test accounts of the critical drivers of trust that explicitly incorporate the particularities of the specific context and one characteristic that is likely to create important differences across relationships is the nature of the salient vulnerabilities (Pirson \&Malhotra, 2011). Despite not necessarily being particular to it, the vulnerabilities perceived by trustors in the NRM context are somewhat different than in, for example, the organizational context. These particularities are likely to activate different concerns in trustors and, as a result, may increase or decrease the importance of various drivers of trust.

A seminal first step in identifying the constructs that drive trust in the NRM context specifically was taken in a qualitative assessment of the 'factors' of trust in the US Army Corps of Engineers (Leahy \& Anderson, 2008). In this study, individuals within a community affected by the Corps were asked simply to discuss their trust in the institution, thereby providing an ideal exploratory investigation of the major themes within NRM trust. The thematic analyses, which were largely supported in a subsequent quantitative investigation (Smith, Leahy, Anderson, \& Davenport, 2013a), revealed five themes or 'factors' that contribute to trust in this context; namely, the participants' trust in others generally, their trust in the federal government, their belief that the Corps cared about the same things they did, their belief that the Corps was able to do its job well and their belief that the procedures used by the Corps were fair.

Many of these same themes repeat throughout the small but noteworthy literature investigating the drivers of trust in the NRM context (e.g. Cvetkovich \& Nakayachi, 2007; Earle \& Siegrist, 2008; Poortinga \& Pidgeon, 2006; Stern, 2008; Winter \& Cvetkovich, 2008, 2010). For example, Stern and Coleman (2015) provide a conceptual argument for the existence of four 'forms' of trust which they explicitly define as the psychological state that accompanies the acceptance of vulnerability. Drawing upon trust scholarship in other areas (e.g. Rousseau et al., 1998), the authors suggest that four constructs from 'trust theory' may be especially important in this context. Specifically, they argue for trust in others, trust based on a calculative evaluation of the trustor's experience and expectations, trust based on the target's social characteristic like care for the trustor and trust based on the fairness of interactions 
between the trustor and target. Similarly, some of the work investigating the trust, confidence and cooperation (TCC) model from the risk management literature (see Earle, Siegrist, \& Gutscher, 2007) has applied its basic arguments to NRM (e.g. Cvetkovich \&Winter, 2003). The TCC model argues especially for the importance and distinctiveness of rational expectations that working with the target will 'go well' as based upon previous experience and a perceived similarity of values between the trustor and target.

Other literatures have also identified important themes within the potential drivers of trust that overlap well with the themes identified above (for a review see Bornstein \& Tomkins, 2015). For example, the most cited model of trust to date argues for the importance of three particular constructs as drivers of organizational trust (Mayer et al., 1995), two of which are the target's ability to do what it is being trusted to do and its care for the trustor. More recently, Pirson and Malhotra (2011) extended Mayer et al. (1995) three antecedents by adding two constructs, one of which was a belief that the target and trustor shared important values.

The scholarship investigating trust in the NRM context is certainly in its infancy but its evaluation does seem to suggest a somewhat consistent, and as yet, largely untested argument regarding the critical drivers of trust. The current research, therefore, takes up this deficiency in arguing that are six theoretically important and conceptually distinct themes that are central to understanding trust in the NRM context. Specifically, we argue that trust is notably driven by trust in others generally (which we call dispositional trust), a belief that the target prioritizes concern for those it serves over its own interests (care), a belief that the target has the ability to do its job well (competence), an expectation about how things will go in working with the target (confidence), a positive evaluation of the fairness of the procedures used by the target (procedural fairness) and a perceived similarity between the values of the trustor and target (salient values similarity).

Dispositional trust refers to the trustor's propensity to trust others across situations and contexts and is therefore the default level of trust afforded to novel targets (Hamm et al., 2013b; Smith et al., 2013a; Stern \& Coleman, 2015). That is, in the absence of other information about it, the target is likely to be trusted to the extent that the trustor trusts more general classes of targets (Leahy \& Anderson, 2008). For the sake of the greatest consistency with the existing literature, we named the 
construct dispositional trust in the current inquiry but it is important to note that this construct is not conceptually different from the theme identified by Leahy and Anderson (2008) which they term social trust. ${ }^{1}$ In the NRM context, dispositional trust likely increases the acceptability of being vulnerable to NRM institutions because the trustor is generally willing to trust, and therefore be vulnerable to, others. This baseline of trust is likely to be especially critical in this context because the increasingly wide-reaching nature of NRM efforts frequently implicates large segments of a public that often lacks knowledge about policy issues (Delli Carpini \& Keeter, 1993).

Care is an evaluation of whether the institution is motivated out of concern for the trustor or its own interests, while competence is the belief that the institution has the technical competency to do its job (Barber, 1983; Mayer et al., 1995; see also Cvetkovich \& Nakayachi, 2007; Leahy \& Anderson, 2008; Poortinga \& Pidgeon, 2006). These constructs are therefore conceptually distinct from dispositional trust because they focus specifically on the target instead of others generally. Care and competence both likely reduce the perceived vulnerability by reassuring the trustor that the target, in the case of care, is not just acting in its own interests and, in the case of competence, is actually capable of doing its job. These evaluations are important in the NRM context because of the potential for harm that flows from the ability of management institutions to make decisions that increase the probability of harm to the trustor by not reflecting the best interests of the public or by reflecting technical deficiencies in its competence.

Although it often suffers from a lack of conceptual distinction from trust and the two are frequently used interchangeably, many have argued that confidence is a somewhat calculative positive expectation about working with the target that is based upon previous experience (Earle et al., 2007; Siegrist, 2010). Thus, like care and competence, confidence is also a specific evaluation of the target, but it is distinct in that it is an expectation of the future that arises from an evaluation of its track record that should be related to, but is expected to be separable from, these other evaluations. In the NRM context, confidence likely reduces the perception of vulnerability by increasing the perceived likelihood that working with the management institution will go well for the trustor and is important in this context because, when present, experience with a management institution is often especially relevant to accepting 
vulnerability to its decisions (Earle et al., 2007).

Procedural fairness is the participant's belief that the procedures used by the target are fair (Tyler, 2006; see also Cvetkovich \& Nakayachi, 2007; Earle \& Siegrist, 2008; Leahy \& Anderson, 2008; Syme, Nancarrow, \& McCreddin, 1999). Although certainly related, procedural fairness is expected to be separable from the evaluations presented above because of its emphasis on procedural evaluations specifically. These are an important concerns in the NRM context because effective management usually requires balancing priorities like biodiversity, conservation, wise use and profit. Although they will not necessarily conflict with each other, these goals often point to different management actions. Procedural fairness is, therefore, especially important in this context because it suggests that the institution's decisions are being made on a level playing field where, even if the vulnerability to undesired outcomes is unchanged, the vulnerability to an unfair outcome is reduced.

Finally, salient values similarity is the trustor's perception that he or she shares important values with the target (Earle et al., 2007; see also Cvetkovich \& Nakayachi, 2007; Poortinga \& Pidgeon, 2006; Vaske, Bright, \& Absher, 2007). It is, therefore, most similar to the conceptualization of care presented above, but is expected to be separable because unlike care (which pits the motivation of the target to advance its self-interest against a concern for those with whom it works), salient values similarity focuses specifically on the alignment of the values of the trustor with those of the target. In this context, salient values similarity decreases the vulnerability in working with the target because the fact that the target shares salient values with the trustor should make it more likely that both would act similarly. This is also important because of the vulnerability that can arise from the recognition that the core purposes of NRM institutions and stakeholders often differ but, unlike procedural fairness, this construct focuses specifically on the alignment of values rather than the process by which they are dealt with. A stakeholder is likely to envision themselves as much more vulnerable to an NRM institution that only values biodiversity than to an institution that also shares their value of keeping land productive.

\section{The current inquiry}

The relevant scholarship has a good deal to say about trust in NRM, but the development of the scholarship of trust in this context is challenged 
in two critical ways. The first and most important limitation is the paucity of research that has quantitatively investigated the dimensionality and relative influence of the drivers. Advancing the social science of trust and improving practical efforts involving it requires a nuanced understanding of the relevant constructs' distinctiveness and independent influence. Without this understanding, it remains as likely that there are one or two distinct drivers that are most important in this context as it is that the constructs and their effects are essentially indistinguishable. This matters because if there are distinct drivers that are especially predictive of trust, those constructs should be the focus of trust-enhancing efforts. If not, NRM institutions can design these efforts much more generally as they are just as likely to benefit from increases in any number of drivers. Relatedly, the strongly correlated nature of these constructs demands careful attention to measure development that has often been overlooked. For example, although some researchers do use similar measures across their work, there are still very few multi-item measures of these six drivers with strong evidence for validity in this context (for a noteworthy exception, see Smith, Leahy, Anderson, \& Davenport, 2013b). Instead a significant portion of the NRM trust scholarship typically uses only single item measures - thereby exacerbating potential measurement error concerns - or uses a series of face-valid items for which only limited measures of reliability or dimensionality are reported (e.g. Cronbach's alpha and exploratory factor analyses).

The second noteworthy limitation of the NRM trust research regards a lack of investigation into the conditions under which the specific drivers of trust are most predictive. One promising such moderator is the knowledge and experience (sophistication) of the trustor with the target (Hamm et al., 2013a). A great deal of work in NRM has focused on measuring trust in moderately to highly sophisticated individuals; that is, individuals with a moderate to high level of relevant knowledge about and experience with the focal institution (e.g. Payton, Fulton, \& Anderson, 2005; Smith et al., 2013a; Stern, 2008). The logic is typically that individuals who are most involved in and knowledgeable about natural resource issues are the most likely to act either in the assistance of or opposition to these institutions' actions. Despite the soundness of this logic, the increasingly cross-cutting nature of NRM issues implicates persons who would not otherwise have had contact with these institutions. Thus, NRM institutions are increasingly reliant upon these persons of lower sophistication for cooperative behaviors like granting access to 
private land and engaging in conservation-oriented land management on their property. Problematically, however, the relationship of the various trust drivers to these behaviors as a function of trustors' sophistication is not yet well understood in this context.

The idea that sophistication may be an important moderator of the effects of trust drivers is not a new one (Mayer et al., 1995). In the NRM context, research with students has suggested that dispositional trust is only important for relatively unsophisticated participants, whereas evaluations of the institution became more important with greater sophistication (Hamm et al., 2013b; see also Leahy \& Anderson, 2008). Drawing from research in this and other contexts (e.g. Earle et al., 2007; Herian, Hamm, Tomkins, \& PytlikZillig, 2012), researchers have thus posited the sophistication moderation hypothesis, which suggests that trustors with limited sophistication must base their trust in the target on more general constructs like dispositional trust, for lack of more relevant information (Hamm et al., 2013a). With increased information, however, more directly relevant evaluations can form and become important (but see Lubell, 2007, who suggests a reverse effect can also occur).

In order to address these gaps in the existing literature, the current research presents a model of trust in NRM institutions that includes and explicitly hypothesizes the relationships among the six major drivers of trust in this literature, their relationship to cooperation, and the moderation of that relationship by sophistication. Specifically, the current inquiry hypothesizes that the trust items used here will be reliable and unidimensional indicators of six distinct constructs (H1). The development of these items will be discussed further in the method section, but we expect that, in line with the conceptual distinctiveness postulated above, these carefully crafted measures of the constructs will prove statistically separable. We further hypothesize that because of their role in addressing the willingness to accept vulnerability that is critical for cooperation, the six hypothesized drivers of trust will be significantly related to intention to cooperate with a NRM institution (H2). Finally, we hypothesize that, in line with the sophistication moderation hypothesis, the relationships between the drivers of trust and cooperation will be moderated by the sophistication of the trustor which we operationalize as the trustor's knowledge about and experience with the target (H3). We expect that for persons of limited sophistication, dispositional trust will be most predictive of cooperation. With increased sophistication, 
however, the more institution-specific constructs - care, competence, confidence, procedural fairness and salient values similarity - will become more predictive and will displace the effect of dispositional trust.

\section{Method}

\section{Context}

Contemporary NRM institutions, as stewards of common-pool resources, typically rely heavily upon the public in managing natural resources (Vollan \& Ostrom, 2010). NRM institutions in Nebraska, however, stand in an especially complicated position because more than $95 \%$ of the state's land area is privately owned. Therefore, Nebraska's NRM institutions often lack the legal jurisdiction to levy punishments against land owners who fail to cooperate with their efforts. This, coupled with the substantial resources necessary for incentivizing land owners' behavior, means that these institutions are typically best served by encouraging internally motivated cooperation for which trust is routinely important.

One natural resource institution in Nebraska that is particularly reliant upon voluntary cooperation with its efforts is the Nebraska Game and Parks Commission. The Commission maintains authority over 'state parks, game and fish, recreation grounds, and all things pertaining thereto' (Neb. Revised Statutes, §37-301). One of the areas within the Commission's purview that is especially reliant on voluntary cooperation is land owners' willingness to grant it access to privately owned land for conservation action or to open the land for recreational use as managed by the Commission. Cooperation with these programs is especially important for the Commission's ability to operate effectively in its focus areas along the Platte and Missouri Rivers in Nebraska but these kinds of programs have a long history throughout the USA (e.g. Wigley \& Melchiors, 1987).

\section{Participants}

One thousand six hundred and seventeen land owners with more than 20 acres of rural land were randomly selected from list of all eligible land owners in 44 Nebraska counties by Survey Sampling International (the 
sample size was chosen to achieve 600 responders as recommended by an a priori power analysis, assuming a response rate of approximately $30 \%$ ). The sample was then mailed a cover letter, a paper copy of the survey, \$1 cash incentive and business reply envelope. ${ }^{2}$ Ten days later, all nonresponders were mailed a reminder postcard and, 10 days after the postcard, a replacement survey packet, without the incentive. A total of 645 land owners returned the survey (a response rate of 38\%). The majority of the resulting sample self-reported as male (77\%), White (96\%), and owning more than 100 acres of rural land (75\%). The plurality of the sample was Republican (50\%) and conservative (37\%) or leaning conservative (an additional 17\%), and the sample had an average age of 61 years.

\section{Measures}

Respondents completed an eight-page paper survey that included measures of the drivers of trust, sophistication with the Commission (subjective and objective knowledge and experience), perceived risk, environmental concern (measured using the New Environmental Paradigm-revised (rNEP); Dunlap, Van Liere, Mertig, \& Jones, 2000), and intention to cooperate (see Table 1 for univariate statistics). As suggested by Podsakoff, MacKenzie, Lee, and Podsakoff (2003), the survey was conducted anonymously and all survey items were carefully crafted to ensure precision.

Trust was measured using 20 items developed or amended from existing literature as part of a broader investigation (Tomkins, Bornstein, Herian, \& PytlikZillig, 2011). In that effort, over 100 trust items were iteratively fielded with various student and community samples, evaluated using confirmatory and item factor analytic approaches, and reduced in number until the researchers had three to four item measures of the constructs that consistently yielded good evidence of distinctiveness and reliability. The current measures of dispositional trust, care, competence, confidence, procedural fairness and salient values similarity were taken directly from this larger effort (see Appendix for all items).

Dispositional trust was measured using three items similar those routinely used in the General Social Survey ( http://www3.norc.org/ GSS+Website/ ) that focused on the motivations of 'most people'. Care was measured using three items that assessed whether the trustors 
Table 1. Observed variable univariate statistics.

\begin{tabular}{|c|c|c|c|c|c|}
\hline \multirow[t]{2}{*}{ Construct } & \multirow[b]{2}{*}{$\begin{array}{l}\mathrm{N} \text { of } \\
\text { items }\end{array}$} & & \multicolumn{3}{|c|}{ Averages across items } \\
\hline & & $\begin{array}{c}\text { Cronbach's } \\
\alpha\end{array}$ & Mean & \multicolumn{2}{|c|}{$\begin{array}{l}\text { Standard } \\
\text { deviation }\end{array}$} \\
\hline Dispositional trust & 3 & .81 & 5.02 & \multicolumn{2}{|c|}{0.91} \\
\hline Care & 3 & .80 & 4.49 & \multicolumn{2}{|c|}{1.10} \\
\hline Competence & 4 & .92 & 4.69 & \multicolumn{2}{|c|}{1.09} \\
\hline Confidence & 4 & .94 & 4.79 & \multicolumn{2}{|c|}{1.20} \\
\hline Procedural fairness & 3 & .85 & 4.73 & \multicolumn{2}{|c|}{1.07} \\
\hline Salient values similarity & 3 & .89 & 4.59 & \multicolumn{2}{|c|}{1.21} \\
\hline rNEP & 15 & .87 & 4.20 & \multicolumn{2}{|c|}{0.93} \\
\hline Subjective knowledge & 4 & .92 & 2.29 & \multicolumn{2}{|c|}{0.79} \\
\hline $\begin{array}{l}\text { Intention to cooperate } \\
\text { with conservation } \\
\text { program (no financial } \\
\text { incentive) }\end{array}$ & 1 & (single item) & 3.22 & \multicolumn{2}{|c|}{1.63} \\
\hline $\begin{array}{l}\text { Intention to cooperate } \\
\text { with conservation } \\
\text { program (with financial } \\
\text { incentive) }\end{array}$ & 1 & (single item) & 4.02 & \multicolumn{2}{|c|}{1.62} \\
\hline $\begin{array}{l}\text { Intention to cooperate } \\
\text { with access program } \\
\text { (no financial incentive) }\end{array}$ & 1 & (single item) & 2.87 & \multicolumn{2}{|c|}{1.49} \\
\hline $\begin{array}{l}\text { Intention to cooperate } \\
\text { with access program } \\
\text { (with financial incentive) }\end{array}$ & 1 & (single item) & 3.51 & \multicolumn{2}{|c|}{1.62} \\
\hline Construct & \multicolumn{5}{|c|}{ Response option } \\
\hline $\begin{array}{l}\text { Objective knowledge } \\
\text { (jurisdiction) }\end{array}$ & $\begin{array}{c}\text { Correct } \\
(58 \%)\end{array}$ & $\begin{array}{l}\text { Incorrect } \\
(42 \%)\end{array}$ & & & \\
\hline $\begin{array}{l}\text { Experience } \\
\text { (with staff) }\end{array}$ & $\begin{array}{l}\text { Never } \\
(44 \%)\end{array}$ & $\begin{array}{c}\text { One } \\
\text { time } \\
(10 \%)\end{array}$ & $\begin{array}{c}\text { Once } \\
\text { every } \\
\text { few years } \\
(22 \%)\end{array}$ & $\begin{array}{l}\text { Once } \\
\text { every } \\
\text { year } \\
(18 \%)\end{array}$ & $\begin{array}{c}\text { Monthly } \\
\text { or weekly } \\
(6 \%)\end{array}$ \\
\hline $\begin{array}{l}\text { Perceived risk in } \\
\text { conservation } \\
\text { programs }\end{array}$ & $\begin{array}{c}\text { Yes } \\
(51 \%)\end{array}$ & $\begin{array}{c}\text { No } \\
(49 \%)\end{array}$ & & & \\
\hline $\begin{array}{l}\text { Perceived risk in } \\
\text { access programs }\end{array}$ & $\begin{array}{c}\text { Yes } \\
(61 \%)\end{array}$ & $\begin{array}{c}\text { No } \\
(39 \%)\end{array}$ & & & \\
\hline
\end{tabular}


believed the Commission was motivated out of concern for the public or for itself. Competence was measured using four items that focused on the participant's evaluation of the institution's training and ability to do its job. Confidence, as an expectation of working with the target, was measured using four items that assessed whether the Commission has done and will do its job well. Procedural fairness was measured using three items that assessed whether the Commission has been fair in dealings with the community and with the trustor. Finally, salient values similarity was measured using three items amended from those used by Cvetkovich and Winter (2003) that assessed the degree to which the values of the Commission matched with those of the trustor. Within the paper survey, all respondents saw the trust items in the same randomized order. Across trust scales, the sample typically scored just above the midpoint (4, labelled 'neither agree nor disagree' on a 7-point scale) but was highest on dispositional trust (see Table 1).

Sophistication was measured with items directly addressing subjective knowledge, objective knowledge and experience as recommended in the literature (see Herian et al., 2012). Subjective knowledge was measured using four items regarding the respondent's perceived knowledge about the Commission generally, its practices, policies and goals. Objective knowledge was measured using a single multiple choice question that asked where the Commission can set legally enforceable regulations, and experience was measured using a single item asking how often the respondent had contact with Commission staff. Overall sophistication was relatively low in the sample with subjective knowledge scores below the midpoint of 3 (labelled 'moderately knowledgeable') on a 5-point scale (see Table 1). The sample was roughly evenly divided in accuracy on the objective knowledge question regarding the jurisdiction of the Commission and, regarding experience, most had never had contact and only a little less than a third had contact more than once per year.

Risk was measured using two binary items that asked participants whether they believed that there was any risk involved in granting the Commission access to their land for conservation or public access programs. Approximately half of the sample perceived some level of risk in cooperating with the conservation programs while slightly more of the sample perceived a risk in the access programs (see Table 1).

Environmental concern was measured using the rNEP, which includes 15 items (Dunlap et al., 2000). The revised scale is an update to the older 
NEP scale (Dunlap \& Van Liere, 1978) which has been used extensively to measure environmental worldviews, distinguishes reliably between environmentalists and the general public or non-environmental interest groups, and is predictive of relevant behavior and behavioral intention (see Dunlap et al., 2000). On average, the current sample's item responses were slightly positive (just above the midpoint of 4 , which was labelled 'neither agree nor disagree').

Cooperation intention was measured with four items that assessed intention to cooperate with the efforts of the Commission to manage Nebraska's natural resources effectively. Land owners were asked how likely they felt they were, as of when they completed the survey, to participate in voluntary land owner programs that allowed the Commission to engage in conservation action on their land or allowed the Commission to manage public recreational access to the land. Note that cooperation was assessed for each program both with and without financial incentive, creating the four items (see Appendix). In actuality, these two land owner programs only exist with financial incentive, but because of an interest in the role of trust in predicting cooperation without financial incentive, the extra two questions were included. Repeated measures $t$-tests indicated that all six mean comparisons were significant, such that participants were always more likely to cooperate in the presence of financial incentive, but when incentive was held constant, conservation programs were favored over access programs.

\section{Results}

Analyses were conducted using Mplus v.6 with the maximum likelihoodrobust estimator. ${ }^{3}$ An initial confirmatory factor measurement model including the measures of the six drivers of trust fit well to the data, $\chi^{2}(137)=381.03, p<.001$; Comparative Fit Index (CFI) = .96; Tucker Lewis index $(\mathrm{TLI})=.95$; Standardized Root Mean Square Residual $(\mathrm{SRMR})=.03$, Root Mean Square Error of Approximation $(\mathrm{RMSEA})=$ $.05, p>.05$, but revealed high correlations among five of the six latent constructs (care, competence, confidence, procedural fairness and salient values similarity; see Table 2). Although suggestive of an overdetermined model (one that makes more distinctions than the participants did), a model in which the items (other than the dispositional trust 
Table 2. Trust construct CFA model latent variable correlations (model-based reliability [ $\omega$ ] in the diagonal).

\begin{tabular}{lllllll} 
Construct & 1 & 2 & 3 & 4 & 5 & 6 \\
\hline (1) Dispositional trust & $\omega=.84$ & & & & & \\
(2) Care & $.10^{+}$ & $\omega=.81$ & & & & \\
(3) Competence & $.13^{*}$ & $.95^{* * *}$ & $\omega=.89$ & & & \\
(4) Confidence & $.14^{*}$ & $.98^{* * *}$ & $.94^{* * *}$ & $\omega=.94$ & & \\
(5) Procedural fairness & $.14^{*}$ & $.94^{* * *}$ & $.95^{* * *}$ & $.94^{* * *}$ & $\omega=.85$ & \\
(6) Salient values similarity & $.12^{*}$ & $.93^{* * *}$ & $.87^{* * *}$ & $.92^{* * *}$ & $.92^{* * *}$ & $\omega=.89$ \\
\hline
\end{tabular}

$* * * p<.001$

$* p<.05$

$+p<.10$

items) were entered as indicators of a single factor significantly fit worse, $-2 \Delta \operatorname{LL}(14)=129.92, p<.001 ; \chi^{2}(151)=528.36, p<.001 ; \mathrm{CFI}=.94 ; \mathrm{TLI}=$ .93 ; $\mathrm{SRMR}=.04, \mathrm{RMSEA}=.06, p<.05$, ostensibly because the conceptual distinctions among them were, in fact, meaningful to participants. Thus, to account for the strong covariance among the five latent constructs while still maintaining their conceptual and statistical distinctions, we estimated a model that directly predicted the covariance among the five latent constructs with a higher order factor (see Figure 1). Dispositional trust was again estimated as a separate but correlated latent factor. The higher order model fit well to the data, $\chi^{2}(146)=401.74, p<.001$; CFI $=.96 ; \mathrm{TLI}=.95 ; \mathrm{SRMR}=.03$, RMSEA $=.05, p>.05$, and revealed significant standardized loadings ( $>.90$ ) for all five latent constructs on the higher order factor. Although the higher order model fit significantly worse than the correlated factors model, $-2 \Delta \operatorname{LL}(9)=20.96, p<.05$, the likelihood ratio test (in which differences in the model LL values are chi-square distributed) can be overly sensitive to sample size (Kline, 2011). Thus, the size of our sample may have increased the likelihood that small (arguably meaningless) decrements in model fit would be statistically significant. Given that the high colinearity among the lower order factors would have caused difficulty in testing their unique predictions of intention to cooperate and the fact that the higher order factor model fit well to the data absolutely (and better than the single-factor model $^{4}$ ), we accepted the higher order factor model as the best representation of our data. 


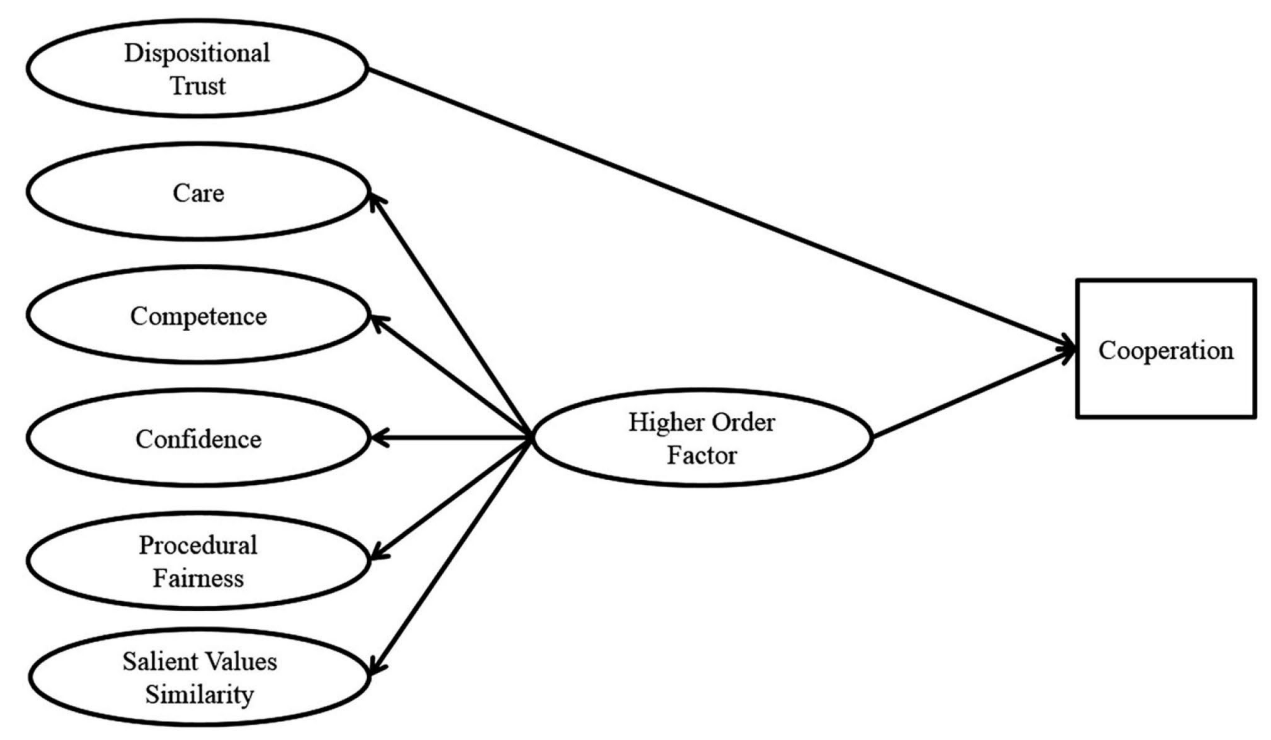

Figure 1. Model of trust in NRM institution (with higher order factor).

To examine the relationship of intention to cooperate with the trust constructs, a structural equation model (SEM) was then estimated that included the four intention-to- cooperate items as observed indicators and estimated their correlations with the higher order factor and the dispositional trust latent factor. The model fit well to the data, $\chi^{2}(214)=$ 503.25, $p$ <.001; CFI = .96; TLI = .96; SRMR $=.03$, RMSEA $=.05, p=.89$, and revealed that while the higher order factor was significantly correlated with each of the intention-to-cooperate indicators $\left(r^{\prime} s>.20\right)$, dispositional trust never was ( $p^{\prime}$ s $\left.>.50\right)$.

We then estimated another model in which the average of the four subjective knowledge items, objective knowledge about the institution's jurisdiction (coded $0=$ wrong; $1=$ correct), reported experience with staff, whether the participant perceived any risk in the specific program (coded $0=$ no risk; 1 = risk), and environmental concern (operationalized as the average of the rNEP items) were also entered as additional observed predictors of the four intention-to-cooperate indicators. Model fit was low but acceptable, $\chi^{2}(334)=759.75, p<.001$; CFI $=.94$; TLI $=$ .93; $\mathrm{SRMR}=.08$; $\mathrm{RMSEA}=.05, p=.41$, and revealed that the higher order factor maintained its significant independent prediction of all four intention-to-cooperate indicators (see Table 3), while dispositional trust never had a significant effect. 
Table 3. SEM regressing intention to cooperate on trust, sophistication, perceived risk and environmental concern.

\begin{tabular}{|c|c|c|c|c|c|}
\hline Criterion & $\begin{array}{l}\text { Variance } \\
\text { accounted }\end{array}$ & Predictor & $\begin{array}{l}\text { Std }_{y x} \\
\text { regression } \\
\text { coefficient }\end{array}$ & $S E$ & $p$-Value \\
\hline \multirow{8}{*}{$\begin{array}{l}\text { Cooperation with } \\
\text { conservation } \\
\text { (no financial } \\
\text { incentive) }\end{array}$} & \multirow{8}{*}{$\begin{array}{l}R^{2}=.08 \\
p=.001\end{array}$} & Higher order factor & .24 & .05 & $<.001$ \\
\hline & & Dispositional trust & -.01 & .05 & .90 \\
\hline & & Perceived risk in & & & \\
\hline & & conservation programs & -.09 & .04 & .03 \\
\hline & & rNEP & .08 & .05 & .10 \\
\hline & & Obj. knowledge (juris.) & -.05 & .05 & .32 \\
\hline & & Subj. knowledge & .08 & .05 & .14 \\
\hline & & Experience (staff) & .03 & .05 & .55 \\
\hline \multirow{8}{*}{$\begin{array}{l}\text { Cooperation with } \\
\text { access } \\
\text { (no financial } \\
\text { incentive) }\end{array}$} & \multirow{8}{*}{$\begin{array}{l}R^{2}=.12 \\
p<.001\end{array}$} & Higher order factor & .21 & .06 & $<.001$ \\
\hline & & Dispositional trust & .01 & .05 & .79 \\
\hline & & Perceived risk in access & -.25 & .04 & $<.001$ \\
\hline & & programs & & & \\
\hline & & rNEP & .05 & .03 & .12 \\
\hline & & Obj. knowledge (juris.) & -.07 & .04 & .17 \\
\hline & & Subj. knowledge & .02 & .05 & .63 \\
\hline & & Experience (staff) & -.03 & .05 & .55 \\
\hline \multirow{7}{*}{$\begin{array}{l}\text { Cooperation with } \\
\text { conservation } \\
\text { (with financial } \\
\text { incentive) }\end{array}$} & \multirow{7}{*}{$\begin{array}{l}R^{2}=.08 \\
p=.001\end{array}$} & Higher order factor & .21 & .06 & $<.001$ \\
\hline & & Dispositional trust & -.001 & .05 & .98 \\
\hline & & $\begin{array}{l}\text { Perceived risk in } \\
\text { conservation programs }\end{array}$ & -.08 & .04 & .06 \\
\hline & & $r N E P$ & .08 & .04 & .03 \\
\hline & & Obj. knowledge (juris.) & -.03 & .05 & .52 \\
\hline & & Subj. knowledge & .11 & .05 & .04 \\
\hline & & Experience (staff) & .07 & .05 & .21 \\
\hline \multirow{8}{*}{$\begin{array}{l}\text { Cooperation with } \\
\text { access } \\
\text { (with financial } \\
\text { incentive) }\end{array}$} & \multirow{8}{*}{$\begin{aligned} R^{2} & =.09 \\
p & <.001\end{aligned}$} & Higher order factor & .21 & .05 & $<.001$ \\
\hline & & Dispositional trust & .01 & .05 & .88 \\
\hline & & Perceived risk in access & -.17 & .04 & $<.001$ \\
\hline & & programs & & & \\
\hline & & rNEP & .06 & .03 & .054 \\
\hline & & Obj. knowledge (juris.) & -.08 & .05 & .09 \\
\hline & & Subj. knowledge & .07 & .05 & .19 \\
\hline & & Experience (staff) & -.07 & .05 & .21 \\
\hline
\end{tabular}

Italic constructs are significant predictors. 


\section{Moderation model}

In order to test the hypothesis regarding the moderation of the relationships by land owner sophistication, it was first necessary to conduct a series of measurement invariance tests, in which separate but simultaneous models were estimated for individuals who were high or low on each sophistication construct (objective knowledge regarding the institution's jurisdiction, subjective knowledge about the institution generally, and experience with its staff). ${ }^{5}$ After testing the measurement invariance of the models across levels of subjective knowledge, the moderation of the effects of the higher order and dispositional trust factors on the four intention-to-cooperate indicators by subjective knowledge was tested (see Table 4). Contrary to the hypothesis, none of these comparisons were significant, indicating that the regressions were statistically equivalent for individuals above and below the mean of subjective knowledge.

Following a similar procedure, measurement invariance across low and high objective knowledge of the institution's jurisdiction and the moderation of the effects of the higher order and dispositional trust factors on intention to cooperate were tested. As shown in Table 4, three of these effects were significant. Specifically, for the conservation program without financial incentive, individuals who were low in objective knowledge had a stronger, but still non-significant absolute effect for dispositional trust on intention to cooperate $\left(\beta_{\text {low }}=-0.11 ; p=.12 ; \beta_{\text {high }}\right.$ $=0.05 ; p=.29$ ). Similarly, for access programs without financial incentive, individuals who were low in objective knowledge (low sophistication) had a stronger absolute effect for dispositional trust on intention to cooperate $(\beta=-0.12 ; p=.09)$ than did individuals who were higher in objective knowledge ( $\beta=0.06 ; p=.22$ ) while the opposite was true for the higher order trust factor $\left(\beta_{\text {low }}=0.16 ; p=.02 ; \beta_{\text {high }}=0.34 ; p<.001\right)$.

Finally, the moderation of the effects of the higher order and dispositional trust factors by experience was tested. Only one effect differed between groups, such that, for the access program without financial incentive, individuals with more experience (high sophistication) had a stronger effect of the higher order factor predicting intention to cooperate $(\beta=0.41 ; p<.001)$ than individuals with less experience $(\beta=0.15$; $p=.14)$. 
Table 4. Sophistication moderation tests.

\begin{tabular}{|c|c|c|c|c|}
\hline $\begin{array}{l}\text { Intention-to- } \\
\text { cooperate variable }\end{array}$ & $\begin{array}{l}\text { Trust } \\
\text { variable }\end{array}$ & $\begin{array}{l}\text { Subjective } \\
\text { knowledge }\end{array}$ & $\begin{array}{l}\text { Objective } \\
\text { knowledge }\end{array}$ & Experience \\
\hline \multirow{2}{*}{$\begin{array}{l}\text { Cooperation with } \\
\text { conservation } \\
\text { (no financial } \\
\text { incentive) }\end{array}$} & $\begin{array}{l}\text { Dispositional } \\
\text { trust factor }\end{array}$ & Non-significant & $\begin{array}{l}\text { Effect stronger } \\
\text { with less } \\
\text { sophistication }^{\mathrm{a}}\end{array}$ & Non-significant \\
\hline & $\begin{array}{l}\text { Higher order } \\
\text { factor }\end{array}$ & Non-significant & Non-significant & Non-significant \\
\hline \multirow{2}{*}{$\begin{array}{l}\text { Cooperation with } \\
\text { conservation } \\
\text { (with financial } \\
\text { incentive) }\end{array}$} & $\begin{array}{l}\text { Dispositional } \\
\text { trust factor }\end{array}$ & Non-significant & Non-significant & Non-significant \\
\hline & $\begin{array}{l}\text { Higher order } \\
\text { factor }\end{array}$ & Non-significant & Non-significant & Non-significant \\
\hline \multirow{2}{*}{$\begin{array}{l}\text { Cooperation with } \\
\text { access (no } \\
\text { financial } \\
\text { incentive) }\end{array}$} & $\begin{array}{l}\text { Dispositional } \\
\text { trust factor }\end{array}$ & Non-significant & $\begin{array}{l}\text { Effect stronger } \\
\text { with less } \\
\text { sophistication }{ }^{a}\end{array}$ & Non-significant \\
\hline & $\begin{array}{l}\text { Higher order } \\
\text { factor }\end{array}$ & Non-significant & $\begin{array}{l}\text { Effect stronger } \\
\text { with more } \\
\text { sophistication }^{\mathrm{a}}\end{array}$ & $\begin{array}{l}\text { Effect stronger } \\
\text { with more } \\
\text { sophistication }^{\text {a }}\end{array}$ \\
\hline \multirow{2}{*}{$\begin{array}{l}\text { Cooperation with } \\
\text { access (with } \\
\text { financial } \\
\text { incentive) }\end{array}$} & $\begin{array}{l}\text { Dispositional } \\
\text { trust factor }\end{array}$ & Non-significant & Non-significant & Non-significant \\
\hline & $\begin{array}{l}\text { Higher order } \\
\text { factor }\end{array}$ & Non-significant & Non-significant & Non-significant \\
\hline
\end{tabular}

a. A hypothesis consistent result.

\section{Discussion}

These results provide support for the hypothesized dimensionality of the six major constructs that drive trust in the NRM context (H1): Confirmatory factor analyses revealed that six factors sufficiently accounted for the covariance in responses. Importantly, however, the extremely high correlations among five of these (care, competence, confidence, procedural fairness and salient values similarity) suggest this solution may not be especially practical. Functionally, this high colinearity precluded the evaluation of the independent effects of each factor in predicting cooperation outcomes, but it could also challenge the conceptual 
distinctiveness of the constructs themselves. Given that five of the trust constructs shared most of their variance $(>75 \%$ in the latent variable analyses), they could be considered equivalent, such that five separate factors are unnecessary. Our analysis did not support this position, however, as a single-factor model fit significantly worse. Additionally, evaluation of several alternative model specifications - including other models that were recommended by modification indices - failed to yield a better fitting model. Instead, our results suggest that although these trust constructs are very strongly related, they are statistically distinct and this makes sense conceptually as well. Despite the conceptual overlap in perceptions of care, salient values similarity and procedural fairness, it is certainly possible for an institution to care about the public generally, but not to share the values of the trustor nor offer the opportunity for voice in its decision-making processes. Perceptions of competence may be even more distinct, as it is not hard to imagine an institution that is very competent but places little emphasis on its interactions with the public. Indeed, some of the lowest institution-specific construct correlations in the analyses here were between competence and the other drivers of trust. Even so, these constructs are likely to overlap somewhat with competence. Confidence, for example, likely overlaps in that institutions tend to do their jobs well when they are sufficiently competent to do so.

To address the functional issue of insufficient unique variance in predicting cooperation outcomes, a higher order factor was included. Thus, the primary rationale for its inclusion is pragmatic, but it does suggests a potential conceptual development in the understanding of trust that, although not entirely novel (see also Van de Walle \& Bouckaert, 2003), is certainly not a majority position in the trust literature. Specifically, it may be that when responding about specific perceptions of an institution, individuals rely heavily upon a more global evaluation of it. Thus, institutions that are perceived positively overall may also be perceived as caring, competent, fair, etc., not because the trustor has evaluated and responded to each construct individually, but because of a positive overall impression. This, however, does not preclude the possibility that in some situations, individuals may have distinct perceptions of the various drivers of trust (e.g. immediately after learning that an especially positively perceived target is low in competence). Indeed, the differential effects of specific drivers of trust in some scholarship seems 
to provide direct evidence of this (e.g. Hamm et al., 2013a, 2013b; Pirson \&Malhotra, 2011).What these results do suggest, however, is that for most individuals, most of the time, the institution-specific drivers of trust are likely to cohere strongly, and at least one possible explanation for this is because of their shared basis in an underlying, more global evaluation of the target.

Although our data do not speak directly to the nature of this underlying evaluation, some guidance can be elicited from the broader literature of trust. Although the field as a whole still suffers from a lack of a common understanding of the construct (Bornstein \& Tomkins, 2015), it is converging on a common definition. As discussed in the introduction, this conceptualization suggests that trust is a willingness to accept vulnerability in dealings with an 'other' (McEvily \& Tortoriello, 2011), and that the drivers of trust provide the reasons why an individual would accept that vulnerability (Mayer et al., 1995). Combined with the statistical evidence here that suggests that our respondents may have been relying on a broader evaluation of the institution in determining their responses to measures of the individual drivers, this might mean that individuals' broader evaluation of the institution is their willingness to be vulnerable to it. It is important to note that this conceptualization of trust as a willingness to accept vulnerability that is driven by the other constructs reverses the causality implied by our model, but it stands to reason that these relationships may be somewhat recursive. In the context of a novel target, the trustor would be expected to base his or her level of willingness to accept vulnerability to the institution on the information (drivers) that are available. As this willingness becomes more settled, however, it also stands to reason that it could be itself used as a, and potentially the, basis for other specific evaluations of the institution, especially those for which more relevant information is not readily available.

Consider, for example, a land owner who is approached by a new NRM partnership in his area that is seeking his voluntary cooperation by requesting that he engage in patch burning on land that he uses for grazing. The process will require the land owner to select some percentage of his land to be burned periodically and thus be unavailable for grazing. Although the process is expected to increase the suitability of the land for future grazing (e.g. by increasing biodiversity and controlling trees), it is not without its own risk of decreased productivity if the grasses fail 
to return or if too much land is unintentionally burned by an out-of-control grass fire. Assume that the partnership has presented itself as particularly caring and has convinced the land owner that they espouse his most salient value of productivity. In determining his willingness to cooperate, the land owner is likely to take what information is available to him which, in this case, is likely to be the evaluation of its care and salient values similarity. In this situation, the causal direction of the relationship between the constructs and the willingness to be vulnerable is likely to follow that suggested by the conceptualization of trust as a result of its drivers. Assume now, however, that the land owner has no information regarding the competence or procedural fairness of the institution but is asked about his perceptions of these constructs. It stands to reason that these responses may now be driven by the underlying willingness to accept vulnerability in dealing with the institution, such that if he is now generally willing to be vulnerable to the institution, he would also be motivated to feel that it is more competent and more procedurally fair. This would flip the causal direction of the relationship to follow that suggested in the higher order model. Thus, the underlying evaluation, whatever its nature, may operate as both a driver and an outcome of the more specific evaluations as a function of the situation.

The second major proposition of the model tested here is the influence of trust on cooperation and intention to cooperate (H2). This hypothesis was also largely supported, such that the analyses consistently revealed a small but statistically significant effect for institution-specific trust on cooperation. Critically however, this was not the case for dispositional trust. Indeed, dispositional trust was never a significant predictor of any of the operationalizations of cooperation, regardless, even, of the sophistication of the trustor. On its face, this finding runs contrary to the sophistication moderation hypothesis which was the final proposition of the model (H3). According to this hypothesis, less sophisticated individuals (i.e. individuals with less relevant knowledge and experience) should rely more heavily upon more general tendencies to trust others, whereas more sophisticated individuals should rely more heavily upon more target-specific information (Hamm et al., 2013a, 2013b; see also Leahy \& Anderson, 2008; Mayer et al., 1995). Overall, despite a few hypothesis consistent findings, the results mostly failed to support this hypothesis; they suggest instead that our participants relied roughly equivalently on the drivers of trust regardless of their sophistication. 
The rationale for the sophistication moderation hypothesis is that when unsophisticated individuals interact with a novel other, their lack of knowledge and experience with the target means that they will have only more general constructs upon which to rely, like their tendency to trust others generally. Despite the failure of the analyses here to provide clear support for this hypothesis, reason dictates that individuals cannot base evaluations on information they do not have. As a result, unsophisticated individuals cannot base their evaluations of an institution on the institution-specific drivers. Thus, these results likely do not so much provide evidence of the inaccuracy of the hypothesis as they may indicate that the kind of sophistication necessary for the moderation is somewhat particular as may be the requisite level. Unlike the present research, the previous research that supported the hypothesized moderation (Hamm et al., 2013a, 2013b) compared individuals who were moderately to highly sophisticated regarding aspects of the institution that were salient to the specific evaluation (e.g. defendants who had contact with the courts and students who had received specific information about a water allocation) to very unsophisticated individuals (students who reported very little contact with the courts or who had not yet received information about the water allocation). Thus, these samples represent relatively ideal comparisons, in that the unsophisticated individuals were especially lacking in relevant knowledge and experience. This is arguably not the case in the present research, in which sophistication was more similar across respondent groups both in degree (our sophisticated respondents were not that much more sophisticated than our unsophisticated respondents) and in the relevance of the knowledge and experience measured (is knowing an institution's jurisdiction really relevant to being able to separate perceptions of it from your perceptions of others generally?).

\section{Limitations}

Despite the contributions of this research, there are important limitations, especially in terms of generalizability. Although the research utilized a random, and therefore presumably representative sample of rural Nebraska land owners, it was necessarily limited to individuals who were willing to complete a survey about natural resources regulation in the state. While this is likely to include individuals who were both 
especially happy (and thus cooperative) and especially unhappy (and thus motivated to express their discontent) with NRM in Nebraska, this sample, like all survey samples, is limited to respondents who were willing to comply with our participation request. Thus, this survey may well have over-sampled individuals who are dispositionally more willing to comply. It is important to note that our intended cooperation rates were not unduly high, as might have been expected if we had over-sampled dispositionally compliant individuals, but none of the data collected in this research is able to speak directly to this potential problem.

\section{Implications}

From biodiversity to food production and ecosystem services, effectively meeting the plethora of contemporary natural resource challenges via effective management is a critical responsibility of contemporary NRM. After decades of so-called command-and-control approaches, modern NRM institutions generally recognize that more collaborative approaches are preferable and that trust, therefore, has an important role to play in their success. This research investigates the role of trust in this context and in so doing, suggests three important implications that, assuming they generalize, may apply beyond the NRM context to all institutional targets of trust. We therefore suggest that the lessons learned here may be of interest to a wide variety of institutional contexts but note that context-specific tests will be important. As ever, future research is certainly needed.

First, regarding the role of trust, our findings suggest that institutional targets are likely to be well served by enhancing trust but that the referent of trust is critical for this benefit. Although some research has suggested that more diffuse trust constructs might have roles to play (e.g. Nahapiet \& Ghoshal, 1998; Pretty, 2003), our findings regarding dispositional trust suggest that these less specific constructs may be much less important than more institution-specific evaluations. This is encouraging for institutions because it is likely to be these evaluations over which they will have the most control. It would be difficult (but arguably possible) for an institution to affect the level of trust that individuals have in each other generally, but it is much easier to conceive of efforts in which institutional targets could engage to improve perceptions of themselves. These could include efforts that focus on educating the public about their competence and track record; or meetings with 
stakeholders, individually or in groups, to discuss the similarity of salient values; or requesting input via public participation events that provide stakeholders with real voice, a critical consideration for procedural fairness evaluations (Colquitt, Conlon, Wesson, Porter, \& Ng, 2001). Institutions that engage in these efforts will likely experience increased cooperation, at least to the extent that they are able to increase trust.

Unfortunately, however, the clear guidance our findings can provide regarding the specific drivers most critical for cooperation stops at the target. Instead of identifying one or two drivers of trust that most significantly predict cooperation, our analyses identified five latent constructs that are too correlated to permit directly testing their independent effects. To address this concern, a higher order latent construct was used to predict the covariance among these institution-specific constructs and structural regression analyses revealed that it consistently had the strongest relationship with cooperation. As discussed above, these institution-specific evaluations are likely important for improving cooperation, but this finding suggests that the broader institutional evaluation underlying these more specific constructs may, in fact, be most relevant. This would suggest that institutions may be best served by targeting this global evaluation, making an understanding of its nature especially important.

While our findings provide little guidance as to the nature of the underlying construct, consideration in light of the broader literature of trust suggests that it might be a willingness to accept vulnerability. If so, institutions would likely be most efficient in increasing cooperation if they directly address stakeholders' willingness to be vulnerable to them. Such efforts would likely still focus on the individual institutionspecific drivers of trust, but the recognition of vulnerability as the critical consideration should encourage institutions to work to identify the perceived vulnerabilities and focus their efforts there. For example, if an important trustor group perceived an especially salient vulnerability like decreases in productivity, institutional efforts to increase trust that focused on these issues would likely be much more effective in increasing cooperation than efforts focused on less salient vulnerabilities.

The final implication of our findings regards the role of sophistication. Previous research has suggested that institution-specific constructs are more important in predicting cooperation for more sophisticated individuals (e.g. Hamm et al., 2013a, 2013b). If so, then by increasing the trustor's sophistication, institutions could reduce the importance of trust 
in others, which they are unlikely to be able to increase efficiently, in favor of increasing the importance of trust in the institution, which is far more under their control (Hamm et al., 2013b). Although they fail to provide strong support for the hypothesis, the current findings, when considered in light of the previous work, do suggest that the level of sophistication required for institution-specific constructs to dominate models predicting cooperation is relatively low and/or fairly global. Across the relevant analyses, only those including students who reported little contact with the institution (Hamm et al., 2013a) or who had not yet been given more specific information (Hamm et al., 2013b) identified dispositional trust as a major predictor of the relevant criterion. When the sample was highly sophisticated (e.g. defendants; Hamm et al., 2013a) or more moderately sophisticated (as in the present study), however, the importance of dispositional trust was lost in favor of institution-specific trust. Indeed, just a few paragraphs of information were sufficient to eliminate the influence of dispositional trust in a within-groups vignette study (Hamm et al., 2013b). This finding is encouraging for institutions because it suggests that efforts to increase sophistication need only result in relatively low increases in relevant knowledge or experience to reduce the effects of dispositional trust.

\section{Summary and Conclusion}

This research sought to clarify the role of trust - and especially its drivers - in predicting cooperation in the NRM context. Our results indicate that, although separable, five of the six major drivers of trust tested here were very highly related. The evaluation underlying these drivers of trust had a small but consistently significant relationship to cooperation, which was independent of the knowledge, experience and other attitudes of the land owner. Our results suggest three implications that, if they generalize, may be applicable to all institutional targets of trust. First, trust does matter for cooperation, but the target of that trust is critical. Second, institutions will likely be best served by identifying and directly addressing the evaluation underlying the institution-specific drivers of trust. Third, to the extent that the effects of trust depend on trustor sophistication, replacing the influence of dispositional trust with more institution-specific trust likely occurs at relatively low levels of sophistication with the target institution. 
Acknowledgments The authors gratefully acknowledge the assistance of Scott Taylor and Alicia Hardin of the Nebraska Game and Parks Commission, Chris Heltzer of The Nature Conservancy, and Kent Pfeiffer of the Southeast Nebraska Flagship Initiative in conducting this research.

Disclosure None of the authors have any financial interest or have received any benefit arising from the direct applications of this research.

Funding This research was funded, in part, by a National Science Foundation Dissertation Improvement Grant [SES-1154855] and under Grant Numbers [DGE-0903469] and [SES-1061635]. The Nature Conservancy (TNC) also provided partial support for this work through the Nebraska Chapter's J.E. Weaver Competitive Grants Program. Any opinions, findings, and conclusions or recommendations expressed in this material are those of the authors and do not necessarily reflect the views of NSF or TNC.

\section{Notes}

1. Note also that dispositional trust incorporates elements of trust in government (Leahy \& Anderson, 2008) in that trust in government is often a foundation of trust in others more generally (see Tao, Yang, Li, \& Lu, 2013). To facilitate the applicability of the proposed model to both governmental (as investigated here) and non-governmental NRM institutions (e.g. The Nature Conservancy), trust in government was not included here as a distinct construct in the model. We recognize, however, that in some situations, it may be profitable to consider the constructs distinctly, especially when their association is weak.

2. Data collection was conducted by the University of Nebraska-Bureau of Sociological Research ( http://bosr.unl.edu ).

3. The far majority of participants had complete data ( $n=583 ; 90 \%)$, but missing data analyses were conducted to evaluate the influence of demographics, trust and sophistication on missingness in our variables of interest. Count missing variables for our primary constructs were created and regressed on demographics and item average scales of the trust and sophistication measures via generalized models. None of the resulting models were significant, so the data were assumed to be missing completely at random and appropriate for the subsequent analyses.

4. Note that the difference in -2LL between the correlated factors model and the higher order model (20.96 across 9 degrees of freedom) was much smaller than the difference between the correlated factors model and the single-factor model (129.92 over 14 degrees of freedom).

5. Measurement invariance of all six drivers and the higher order factor was examined for the low and high groups of the sophistication moderator variables, including metric (indicator factor loadings), scalar (indicator means) and residual (indicator error) invariance. These invariance tests can identify the extent to which each set of model parameters are statistically equivalent across groups by comparing models with and without equality constraints. If an equality constraint results in a significant decrease in model fit, it indicates that the parameter is not statistically equivalent across groups. In the current situation, invariance testing is important because it determines the extent to which the trust latent factors are being measured equivalently by their items across groups - a necessary precursor to group comparisons. Further details for the subjective knowledge, objective knowledge and experience measurement invariance analyses are available from the first author. 


\section{Contributors}

Joseph Hamm is Assistant Professor of Criminal Justice \& Environmental Science and Policy at Michigan State University. His work focuses on the conceptualization, measurement, and outcomes of trust in institutions, especially institutions of government.

Lesa Hoffman is the Scientific Director of the Research Design and Analysis (RDA) Unit of the Lifespan Institute and Associate Professor of Quantitative Methods at the University of Kansas. Her program of research seeks to empirically examine and to thoughtfully disseminate how developments in quantitative psychology can best be utilized to advance empirical work in psychology, human development, and other social sciences.

Alan Tomkins is currently Acting Director of the Division of Social and Economic Sciences at NSF. He is on-leave from his duties as director of the University of Nebraska Public Policy Center and professor of psychology and law at the University of Nebraska-Lincoln. At Nebraska, he studied public trust in government.

Brian Bornstein is Professor of Psychology and Courtesy Professor of Law at the University of Nebraska-Lincoln, where he is also Director of the Law-Psychology Program. His primary research interests are distributive and procedural justice, jury decision making, and eyewitness testimony.

\section{References}

Armitage, D. R., Plummer, R., Berkes, F., Arthur, R. I., Charles, A. T., Davidson-Hunt, I. J., ... Wollenberg, E. K. (2009). Adaptive co-management for social-ecological complexity. Frontiers in Ecology and the Environment, 7(2), 95-102.

Barber, B. (1983). The logic and limits of trust. New Brunswick, NJ: Rutgers University Press.

Berkes, F. (2009). Evolution of co-management: Role of knowledge generation, bridging organizations and social learning. Journal of Environmental Management, 90(5), 1692-1702.

Bornstein, B. H., \& Tomkins, A. J. (2015). Motivating cooperation and compliance with authority: The role of institutional trust. New York, NY: Springer.

Briske, D. D., Washington-Allen, R. A., Johnson, C. R., Lockwood, J. A., Lockwood, D. R., Stringham, T. K., \& Shugart, H. H. (2010). Catastrophic thresholds: A synthesis of concepts, perspectives, and applications. Ecology and Society, 15(3), article 37. Retrieved from http://www.ecologyandsociety.org/vol15/iss3/art37/

Colquitt, J. A., Conlon, D. E., Wesson, M. J., Porter, C. O. L. H., \& Ng, K. Y. (2001). Justice at the millennium: A meta-analytic review of 27 years of organizational justice research. Journal of Applied Psychology, 86(3), 425-445.

Cvetkovich, G., \& Nakayachi, K. (2007). Trust in a high-concern risk controversy: A comparison of three concepts. Journal of Risk Research, 10(2), 223-237. 
Cvetkovich, G., \& Winter, P. (2003). Trust and social representations of the management of threatened and endangered species. Environment and Behavior, 35(2), 286-307.

Delli Carpini, M. X., \& Keeter, S. (1993). Measuring political knowledge: Putting first things first. American Journal of Political Science, 37(4), 1179-1206.

Dunlap, R. E., \& Van Liere, K. D. (1978). The 'New environmental paradigm': A proposed measuring instrument and preliminary results. Journal of Environmental Education, 9(4), 10-19.

Dunlap, R. E., Van Liere, K. D., Mertig, E. G., \& Jones, R. E. (2000). Measuring endorsement of the new ecological paradigm: A revised NEP scale. Journal of Social Issues, 56(3), 425-442.

Duram, L. A., \& Brown, K. G. (1999). Assessing public participation in U.S. watershed planning activities. Society and Natural Resources, 12, 455-467.

Earle, T. C., \& Siegrist, M. (2008). On the relation between trust and fairness in environmental risk management. Risk Analysis, 28(5), 1395-1414.

Earle, T. C., Siegrist, M., \& Gutscher, H. (2007). Trust, risk perception and the TCC model of cooperation. In M. Siegrist, T. C. Earle, \& H. Gutscher (Eds.), Trust in cooperative risk management: Uncertainty and skepticism in the public mind (pp. 1-49). London: Earthscan.

Flitcrift, R., Dedrick, D. C., Smith, C. L., Thieman, C. A., \& Bolte, J. P. (2010). Trust: The critical element for successful watershed management. Ecology and Society, 15(3), response 3. Retrieved from http://www.ecologyandsociety.org/vol15/ iss $3 /$ resp3/

Folke, C., Carpenter, S., Walker, B., Scheffer, M., Elmqvist, T., Gunderson, L., \& Holling, C. S. (2004). Regime shifts, resilience, and biodiversity in ecosystem management. Annual Reviews of Ecology, Evolution, and Systematics, 35(1), 557-581.

Frederickson, M. (2014). Relational trust: Outline of a Bourdieusian theory of interpersonal trust. Journal of Trust Research, 4(2), 167-192.

Gunderson, L. H., Holling, C. S., \& Allen, C. R. (2010). The evolution of an idea the past, present, and future of ecological resilience. In L. H. Gunderson, C. R. Allen, \& C. S. Holling (Eds.), Foundations of ecological resilience (pp. 423-444). Washington, DC: Island Press.

Hamm, J. A., Lee, J., Trinkner, R., Wingrove, T., Leben, S., \& Breuer, C. (2016). On the cross domain scholarship of trust in the institutional context. In E. Shockley, T. Neal, L. PytlikZillig, \& B. Bornstein (Eds.), Interdisciplinary perspectives on trust: Towards theoretical and methodological integration (pp. 131-156). New York city: Springer Publishing.

Hamm, J. A., PytlikZillig, L. M., Herian, M. N., Bornstein, B. H., Tomkins, A. J., \& Hoffman, L. (2013a). Deconstructing confidence in state courts. Journal of Trust Research, 3(1), 11-31.

Hamm, J. A., PytlikZillig, L. M., Herian, M. N., Tomkins, A. J., Dietrich, H., \& Michaels, S. (2013b). Trust and intention to comply with a water allocation decision: The moderating roles of knowledge and consistency. Ecology and Society, 18(4), article 49. Retrieved from http://www.ecologyandsociety.org/vol18/iss4/art49/ 
Hardin, G. (1968). The tragedy of the commons. Science, 162(3859), 1243-1248.

Herian, M. N., Hamm, J. A., Tomkins, A. J., \& PytlikZillig, L. M. (2012). Public participation, procedural fairness and evaluations of local governance: The moderating role of uncertainty. Journal of Public Administration Research and Theory, 22(4), 815-840.

Holling, C. S. (1973). Resilience and stability of ecological systems. Annual Review of Ecology and Systematics, 4(1), 1-23.

Idrissou, L., van Paassen, A., Aarts, N., Vodouhè, S., \& Leeuwis, C. (2013). Trust and hidden conflict in participatory natural resources management: The case of the Pendjari National Park (PNP) in Benin. Forest Policy and Economics, 27, 65-74.

Kline, R. B. (2011). Principles and practice of structural equation modeling (2nd ed.). New York, NY: Guilford Press.

Leahy, J. E., \& Anderson, D. H. (2008). Trust factors in community-water resource management agency relationships. Landscape and Urban Planning, 87(2), 100-107.

Liljeblad, A., Watson, A. E., \& Borrie, W. T. (2007). A look inside the dynamics of trust: A guide for managers. USDA Forest Service Proceedings RMRS-P-49. Retrieved from the Aldo Leopold Wilderness Research Institute website: http://www. leopold.wilderness.net/pubs/627.pdf

Lubell, M. (2007). Familiarity breeds trust: Collective action in a policy domain. The Journal of Politics, 69(1), 237-250.

Lynam, T., de Jong, W., Sheil, D., Kusumanto, T., \& Evans, K. (2007). A review of tools for incorporating community knowledge, preferences, and values into decision making in natural resources management. Ecology and Society, 12(1), article 5. Retrieved from http://www.ecologyandsociety.org/vol12/iss1/art5/

Martin, J., Runge, M. C., Nichols, J. D., Lubow, B. C., \& Kendall, W. L. (2009). Structured decision making as a conceptual framework to identify thresholds for conservation and management. Ecological Applications, 19(5), 1079-1090.

Mayer, R. C., Davis, J. H., \& Schoorman, F. D. (1995). An integrative model of organizational trust. The Academy of Management Review, 20, 709-734.

McEvily, B., \& Tortioriello, M. (2011). Measuring trust in organizational research: Review and recommendations. Journal of Trust Research, 1(1), 23-63.

Möllering, G. (2013). Trust without knowledge? Comment on Hardin, 'Government without Trust'. Journal of Trust Research, 3(1), 53-58.

Nahapiet, J., \& Ghoshal, S. (1998). Social capital, intellectual capital, and the organizational advantage. The Academy of Management Review, 23, 244-266.

Nienaber, A., Hofeditz, M., \& Romeike, P. D. (2015). Vulnerability and trust in leaderfollower relationships. Personnel Review, 44(4), 567-591.

Ostrom, E. (1998). A behavioral approach to the rational choice theory of collective action: Presidential address, American Political Science Association, 1997. The American Political Science Review, 92(1), 1-22.

Pahl-Wostl, C., Craps, M., Dewulf, A., Mostert, E., Tabara, D., \& Taillieu, T. (2007). Social learning and water resources management. Ecology and Society, 12(2), article 5. Retrieved from http://www.ecologyandsociety.org/vol12/iss2/art5/ 
Payton, M. A., Fulton, D. C., \& Anderson, D. H. (2005). Influence of place attachment and trust on civic action: A study at Sherburne National Wildlife Refuge. Society \& Natural Resources: An International Journal, 18(6), 511-528.

Pirson, M., \& Malhotra, D. (2011). Foundations of organizational trust: What matters to different stakeholders? Organizational Science, 22(4), 1087-1104.

Podsakoff, P. M., MacKenzie, S. B., Lee, J., \& Podsakoff, N. P. (2003). Common method biases in behavioral research: A critical review of the literature and recommended remedies. Journal of Applied Psychology, 88(5), 879-903.

Poortinga, W., \& Pidgeon, N. F. (2006). Prior attitudes, salient values similarity and dimensionality: Toward an integrative model of trust in risk regulation. Journal of Applied Social Psychology, 36(7), 1674-1700.

Pretty, J. (2003). Social capital and the collective management of resources. Science, 302(5652), 1912-1914.

Rousseau, D. M., Sitkin, S. B., Burt, R. S., \& Camerer, C. (1998). Introduction to special topics forum: Not so different after all: A cross-discipline view of trust. The Academy of Management Review, 23(3), 393-404.

Sabatier, P. A., Focht, W., Lubell, M., Trachtenberg, Z., Vedlitz, A., \& Matlock, M. (2005). Collaborative approaches to watershed management. In P. A. Sabatier, W. Focht, M. Lubell, Z. Trachtenberg, A. Vedlitz, \& M. Matlock (Eds.), Swimming upstream: Collaborative approaches to watershed management (pp. 3-21). Cambridge: The MIT Press.

Selin, S. W., Pierskalla, C., Smaldone, D., \& Robinson, K. (2007). Social learning and building trust through a participatory design for natural resource planning. Journal of Forestry, 105, 421-425.

Sharp, E. A., Twaites, R., Curtis, A., \& Millar, J. (2013). Trust and trustworthiness: Conceptual distinctions and their implications for natural resources management. Journal of Environmental Planning and Management, 56(8), 1246-1265.

Siegrist, M. (2010). Trust and confidence: The difficulties in distinguishing the two concepts in research. Risk Analysis, 30(7), 1022-1024.

Smith, J. W., Leahy, J. E., Anderson, D. H., \& Davenport, M. A. (2013a). Community/ agency trust and public involvement in resource planning. Society and Natural Resources: An International Journal, 26(4), 452-471.

Smith, J. W., Leahy, J. E., Anderson, D. H., \& Davenport, M. A. (2013b). Community/ agency trust: A measurement instrument. Society and Natural Resources: An International Journal, 26(4), 472-477.

Stern, M. J. (2008). The power of trust: Toward a theory of local opposition to neighboring protected areas. Society and Natural Resources: An International Journal, 21(10), 859-875.

Stern, M. J., \& Coleman, K. (2015). The multidimensionality of trust: Applications in collaborative natural resource management. Society and Natural Resources: An International Journal, 28(2), 117-132. doi:10.1080/08941920.2014.945062

Syme, G. J., Nancarrow, B. E., \& McCreddin, J. A. (1999). Defining the components of fairness in the allocation of water to environmental and human uses. Journal of Environmental Management, 57(1), 51-70. 
Tao, R., Yang, D. L., Li, M., \& Lu, X. (2013). How does political trust affect social trust? An analysis of survey data from rural China using an instrumental variables approach. International Political Science Review, 35(2), 237-253.

Tomkins, A. J., Bornstein, B. H., Herian, M. N., \& PytlikZillig, L. M. (2011-2014). Testing a three-stage model of institutional confidence across branches of government. Research project funded by National Science Foundation (SES-1061635).

Tyler, T. R. (2006). Psychological perspectives on legitimacy and legitimation. Annual Review of Psychology, 57(1), 375-400.

Van de Walle, S., \& Bouckaert, G. (2003). Public service performance and trust in government: The problem of causality. International Journal of Public Administration, 26(8-9), 891-913.

Vaske, J. J., Bright, A. D., \& Absher, J. D. (2007) Salient values similarity, social trust, and attitudes towards wildland fire management strategies. Fire social science research from the Pacific Southwest Research Station: Studies supported by National Fire Plan Funds (pp. 233-251). Retrieved from http://www.fs.fed.us/ psw/publications/documents/psw gtr209/psw gtr209.pdf

Vollan, B., \& Ostrom, E. (2010). Cooperation and the commons. Science, 330(6006), 923-924.

Warren, M. E. (1999). Democracy and trust. Cambridge: Cambridge University Press.

Washington-Allen, R. A., Briske, D. D., Shugart, H. H., \& Salo, L. F. (2010). Introduction to special feature on catastrophic thresholds, perspectives, definitions, and applications. Ecology and Society, 15(3), article 38. Retrieved from http://www. ecologyandsociety.org/vol15/iss3/art38/

Wigley, T. B., \& Melchiors, M. A. (1987). State wildlife management programs for private lands. Wildlife Society Bulletin, 15, 580-584.

Winter, P. L., \& Cvetkovich, G. T. (2008). The role of trust, knowledge, concern and gender in the prediction of Californians' reactions to fire management. Fire social science research from the Pacific Southwest Research Station: Studies supported by National Fire Plan Funds (pp. 209- 210). Retrieved from http://www.fs.fed.us/ psw/publications/documents/psw gtr209/psw gtr209.pdf

Winter, P. L., \& Cvetkovich, G. (2010). Trust mediates conservation-related behaviors. Ecopsychology, 2(4), 211-219.

Yandle, T., Hajj, N., \& Raciborski, R. (2011). The Goldilocks solution: Exploring the relationship between trust and participation in resource management within the New Zealand Commercial Rock Lobster Fishery. The Policy Studies Journal, 39(4), 631-658. 


\section{Appendix. Construct measures}

\begin{tabular}{|c|c|}
\hline Construct & Item wording \\
\hline Dispositional trust & $\begin{array}{l}\text { Generally speaking, I would say that most people can be } \\
\text { trusted } \\
\text { I think that most people would try to be fair } \\
\text { I would say that most of the time people try to be helpful }\end{array}$ \\
\hline Care & $\begin{array}{l}\text { For the most part, the decisions made by Game and Parks } \\
\text { are made out of care and concern for area residents } \\
\text { Most decision makers of Game and Parks care about } \\
\text { residents in the area they regulate } \\
\text { The decision makers of Game and Parks put aside their } \\
\text { own personal interests in making decisions that are } \\
\text { right for the community }\end{array}$ \\
\hline Competence & $\begin{array}{l}\text { Most decision makers of Game and Parks are competent to } \\
\text { do their jobs } \\
\text { Most decision makers of Game and Parks are highly } \\
\text { qualified individuals } \\
\text { Most Game and Parks decision makers have the knowledge } \\
\text { necessary to do their jobs } \\
\text { Most Game and Parks decision makers have the skills } \\
\text { necessary to do their jobs }\end{array}$ \\
\hline Confidence & $\begin{array}{l}\text { My confidence in Game and Parks is high. } \\
\text { Game and Parks does its job well } \\
\text { I have confidence in Game and Parks to do its job } \\
\text { I believe Game and Parks will perform its functions as it } \\
\quad \text { should }\end{array}$ \\
\hline Procedural fairness & $\begin{array}{l}\text { The procedures by which Game and Parks decision makers } \\
\text { make decisions are fair } \\
\text { In my experience, Game and Parks generally has been fair } \\
\text { in their dealings with the community } \\
\text { I have generally been treated fair by Game and Parks }\end{array}$ \\
\hline Salient values similarity & $\begin{array}{l}\text { I believe Game and Parks shares my values about how } \\
\text { natural resources should be regulated } \\
\text { To the extent that I understand them, I share Game and } \\
\text { Park's values about how natural resources should be } \\
\text { regulated } \\
\text { I believe that Game and Parks supports my values about } \\
\text { natural resources allocation }\end{array}$ \\
\hline Subjective knowledge & $\begin{array}{l}\text { How knowledgeable do you feel you are about the } \\
\text { Nebraska Game and Parks Commission generally? } \\
\text { How knowledgeable do you feel you are about the practices } \\
\text { of the Nebraska Game and Parks Commission? } \\
\text { How knowledgeable do you feel you are about the policies } \\
\text { of the Nebraska Game and Parks Commission? } \\
\text { How knowledgeable do you feel you are about the goals of } \\
\text { the Nebraska Game and Parks Commission? }\end{array}$ \\
\hline
\end{tabular}




\begin{tabular}{|c|c|}
\hline Construct & Item wording \\
\hline Objective knowledge & $\begin{array}{l}\text { The Nebraska Game and Parks Commission can set legally } \\
\text { enforceable regulations in what areas? (select the } \\
\text { single best answer) }\end{array}$ \\
\hline Experience & $\begin{array}{l}\text { How often do you personally have contact with the } \\
\text { Nebraska Game and Parks Commission staff? }\end{array}$ \\
\hline Risk & $\begin{array}{l}\text { Do you believe that there is any risk to you involved in } \\
\text { granting the Game and Parks access to your land } \\
\text { for the conservation programs? (Note that we are } \\
\text { interested in any risk you might perceive regardless of } \\
\text { how likely or problematic you believe it is.) } \\
\text { Do you believe that there is any risk to you involved in } \\
\text { granting the Game and Parks access to your land for } \\
\text { the access programs? (Note that we are interested in } \\
\text { any risk you might perceive regardless of how likely or } \\
\text { problematic you believe it is.) }\end{array}$ \\
\hline \multirow[t]{10}{*}{ rNEP } & $\begin{array}{l}\text { We are approaching the limit of people the earth can } \\
\text { support }\end{array}$ \\
\hline & $\begin{array}{l}\text { Humans have the right to modify the natural environment } \\
\text { to suit their needs }\end{array}$ \\
\hline & $\begin{array}{l}\text { When humans interfere with nature it often produces } \\
\text { disastrous consequences }\end{array}$ \\
\hline & $\begin{array}{l}\text { Human ingenuity will ensure that we do NOT make the } \\
\text { earth unlivable }\end{array}$ \\
\hline & Humans are severely abusing the environment. \\
\hline & $\begin{array}{l}\text { The earth has plenty of natural resources if we learn how } \\
\text { to develop them }\end{array}$ \\
\hline & $\begin{array}{l}\text { Plants and animals have as much right to as humans to } \\
\text { exist }\end{array}$ \\
\hline & $\begin{array}{l}\text { The balance of nature is strong enough to cope with the } \\
\text { impacts of modern industrial nations }\end{array}$ \\
\hline & $\begin{array}{l}\text { Despite our special abilities humans are still subject to the } \\
\text { laws of nature }\end{array}$ \\
\hline & Construct Item wording \\
\hline \multirow[t]{6}{*}{ rNEP } & $\begin{array}{l}\text { The so-called 'ecological crisis' facing humankind has been } \\
\text { greatly exaggerated }\end{array}$ \\
\hline & $\begin{array}{l}\text { The earth is like a spaceship with very limited room and } \\
\text { resources }\end{array}$ \\
\hline & Humans were meant to rule over the rest of nature \\
\hline & The balance of nature is very delicate and easily upset \\
\hline & $\begin{array}{l}\text { Humans will eventually learn enough about how nature } \\
\text { works to be able to control it }\end{array}$ \\
\hline & $\begin{array}{l}\text { If things continue on their present course, we will soon } \\
\text { experience a major ecological catastrophe }\end{array}$ \\
\hline
\end{tabular}




\section{Construct Item wording}

Intention to cooperate As of today, how likely are you to voluntarily participate in Nebraska Game and Parks Commission conservation programs that do NOT provide financial incentive?

As of today, how likely are you to voluntarily participate in Nebraska Game and Parks Commission conservation programs that DO provide financial incentive?

As of today, how likely are you to voluntarily participate in Nebraska Game and Parks Commission access programs that do NOT provide financial incentive?

As of today, how likely are you to voluntarily participate in Nebraska Game and Parks Commission access programs that DO provide financial incentive? 